\title{
Pedagogical Purposes of Narratives in Worldview Education: Teachers' Conceptions
}

\author{
Raili Keränen-Pantsu* \\ University of Eastern Finland \\ Joensuu, Finland \\ Hannu Heikkinen \\ University of Jyväskylä \\ Jyväskylä, Finland
}

\begin{abstract}
This study explores teachers' pedagogical purposes for using narratives in Finnish religious and worldview education. The article stems from a philosophical and pedagogical view on narrative cognition as a fundamental element of worldview education. Teachers work as interpreters of the cultural stock of stories, including culturally fundamental religious narratives, and convert it into a pedagogical tool for identity work. The research data consists of interviews with primary school class teachers $(\mathrm{N}=6)$ about using narratives in the context of worldview education. Using qualitative content analysis as a research method, four main categories were identified. Teachers used the narratives: (1) to offer knowledge about religions and worldviews to their pupils; (2) to help their pupils to reflect on existential and transcendental issues; (3) to develop pupils' ethical abilities; and (4) to promote pupils' sense of community. Narratives are used in diverse ways; teachers use narratives in a dialogical manner in teaching, and pupils are encouraged to share their own thoughts and ideas. The narrative approach in worldview education provides means for teachers to promote conditions for a safe space and promote dialogue enabling worldview reflection. Narratives have a lot to offer for pluralistic and polyphonic education, opening up diverse ways of viewing the world. The study confirms that the narrative approach offers promising potential for worldview education but, given the restrictions of the small sample of this study, further research is needed.
\end{abstract}

Keywords: worldview education; religious education; teachers; narrative; pedagogy.

*Corresponding author: Raili Keränen-Pantsu, railike@student.uef.fi 


\section{Introduction}

The aim of this article is to explore teachers' conceptions of the pedagogical purposes of narratives in worldview education, which in this case means religious education and secular ethics in the context of Finnish primary schools. A fundamental presupposition of our study is the view that human knowledge, generally speaking constitutes narratives to a large extent, and the narrative form of knowledge has a significant role in teaching about and through worldviews (Geerz \& Jensen, 2014).

There are many ways to understand the term 'worldview'. It could refer to organized worldview systems or ideologies that are present in the world and that different religions such as Christianity or Buddhism are offering. It could also refer to a more personal way of understanding the world and giving answers to questions 'who am I?' and 'where do I belong?' At the personal worldview level, one gives meanings and answers to existential questions of one's place in the world (van der Kooij, de Ruyter, and Miedema 2015). Selcuk and Valk (2012) also offer a transdisciplinary worldview approach, where the world is seen as a meaningful whole. Both religious and non-religious worldviews provide perspectives on ontological, existential, and epistemological questions on a personal, social, and cultural levels.

Worldview education does not only offer knowledge about different religions or belief systems but provides tools for reflection of one's personal worldview (Miedema, 2014). This definition is rather broad and encapsulates several subjects taught in schools, including history, arts, biology, and geography. In the present study, however, we use the term 'worldview education' in a narrow sense, focusing on two school subjects in Finland: secular ethics and religious education (later RE), which are divided into 11 different curricula (e.g. Lutheran RE, Orthodox RE, Islamic RE, etc.) (National Core Curriculum for Basic Education [NCCBE], 2014).

Even though RE is divided into different curricula according to a 'pupil's own religion', the aims of RE are the same in every form of RE. The main goal is to emphasize the development of a pupil's religious literacy (NCCBE, 2014, 264). Moore (2016) understands religious literacy as an ability to separate and analyze intersections of religion and political, social, and cultural life in multiple perspectives. Heimbrock (2001) sees religious literacy as an ability to be tolerant, to act in an ethical way, and active dialogue on religious and worldview issues. It also includes an ability to understand and manage diversity and pluralism in a constructive manner. The aim of RE is to provide the pupils with an extensive general knowledge and ability regarding religion and worldviews (NCCBE, 2014, 264) and secular ethics to promote the pupils' ability to pursue a good life (NCCBE, 2014, 272). In the Finnish curriculum, narratives are presented as tools to promote knowledge about religious, religious literacy and ethical thinking (NCCBE, 2014, 265-266). However, in secular ethics the narratives are not mentioned as directly but can be understood to include to come contents like Finnish culture (NCCBE, 2014, 273). 
In Finland, all pupils are expected to familiarize themselves with different religions and worldviews and examine ethical dimensions of life from their own viewpoint as well as broader phenomena. The curriculum also stresses the understanding of the meaning of religions and worldviews on personal, social, cultural, and global levels. What is worth noting is that both RE and secular ethics as subjects are aimed at supporting the general aim of basic education: growth as a human being and membership of society (NCCBE, 2014, 20) through emphasizing the development of ethical competence and critical thinking, pupil's agency, identity development, and intercultural skills.

According to the Finnish legislative documents (National Core Curriculum for Basic Education, 2014; Basic Education Act 628/1998, $13 \S(6.6 .2003 / 454)$ worldview education must be non-confessional and non-binding. Even though worldview education WE is organized denominationally, it follows the national guidelines imposed by the Finnish National Agency for Education, which means that it is committed to liberal educational values, such as rationality, autonomy, and tolerance (see e.g. Halstead \& Taylor 1996). Religious content such as narratives are understood as a source for ethical thinking and an element for supporting the wider development of the pupil's individual identity (NCCBE, 2014, 268-269). In Finland, the aims of worldview education are strongly related to broad educational areas such as citizenship education and human rights education (see e.g. Åhs, Poulter, \& Kallioniemi, 2017). When making a more detailed review of religious education, Finnish RE draws from the models of teaching about and from religion (Grimmit, 1987) where teaching about religion contains, for example, exploration of the nature of religion, religious practices and festivals, and skills for ethical thinking and interpretation from a study-ofreligion approach. Teaching from religion can function as a source for identity development. Pupils learn through reflecting their own ideas, meaning-making and values. They are active agents, reflect their own worldview and are oriented to learning from other worldviews. Teaching into religion, where the aim is to strengthen the religious identity of the pupils and their commitment to a given religious community, is no longer appropriate (Grimmit, 1987) (for more about the Finnish model, see e.g. Kallioniemi \& Ubani, 2016).

In this study, our focus is on teachers' pedagogical purposes of perceptions of narratives in their worldview education. Our epistemological premise is that the narrative form of knowing is characteristic of religions (Smart, 1989; 1996; 2008; Geerz \& Jensen, 2014), so it is evident that teaching about religions or worldviews has a lot to do with stories. This postulate has also been acknowledged in research literature. For example, Ninian Smart, a Scottish pioneer of secular religious studies $(1989,1996,2008)$, distinguishes narrativity as one of the seven dimensions of religions and worldviews. Moreover, Geerz and Jensen (2014) pinpoint that narrative is perhaps one of the single most important interfaces between intrapersonal and interpersonal meaning production, which also occurs in religions and worldviews.

However, despite the obvious interfaces, there seems to be relatively little research about narrative pedagogy in worldview education, with a few 
exceptions (e.g. Erricker \& Erricker, 2000). More generally, the volume of research on narratives in education is also relatively small, again with some exceptions (e.g. Egan \& McEwan, 1995; Clark \& Rossiter, 2008; Goodson \& Gill, 2011), compared to general research literature and the growing interest in narrativity in research and in society.

In the present paper, we are suggesting that worldviews are largely configured through narratives. We are interested in understanding the pedagogical way teachers use narratives, so the research question is 'for what purpose do teachers use narratives in worldview education?'

Our approach has been inspired by a recent a change in the knowledge culture of social sciences, which has been called a 'narrative turn', and sometimes also a 'narrative boom' or 'narrative explosion' (Hänninen, 2004). This turn to narrative has been regarded not only as a paradigm shift in the academy but a more general cultural change in society, and has also influenced research on religions, education and pedagogy. Some scholars locate the starting point of the narrative turn about 50 years ago. Actually, according to Hyvärinen (2010), we should talk about four different narrative turns with different agendas and attitudes. He locates the first turn in literary theory in the 1960s; the second in historiography following literary narratology; the third in social sciences from the 1980s onwards; and finally, the fourth turn as a more general sociocultural turn to narrative in society, which is much broader and more multifaceted than the academic turns and still needs more careful analysis. Hyvärinen (2010) points out, however, that there is no simple plotline or causal chain between these layers or dimensions of narrativity. However, by the 1990s, claims to acknowledge narrative cognition (Bruner, 1987) as an eligible alternative in scientific research increased. It was recognized not only as a possible approach in research but as a necessary condition for understanding human life on its own terms. (Heikkinen, 2002.) Narrative cognition has a central role in worldview education, and its significance can be found even at the ontological and epistemological levels of religions and worldview systems, since they are configured narratively to a significant extent. The ontological and epistemological foundations are, in turn, reflected at the pedagogical level.

As Biesta and Miedema (2002) point out, pedagogy is always holistic in nature, where the whole person is involved, not only his or her cognition, but also his or her feelings, beliefs, attitudes, values, emotions, volitions, habits, predispositions, and actions. The logical link between pedagogy and narrativity is articulated by theories developed by Clark and Rossiter (2008) and Goodson and Gill (2011). Goodson and Gill (2011) distinguish three different ways of narrative learning: learning from stories; learning in the process of narrating; and learning by contextualizing autobiographical narrative such as one's own life story. Clark and Rossiter (2008), on the other hand, differentiate learning through stories as follows: learning by hearing stories; learning by telling them; and learning by recognizing stories. Recognizing stories in this context means that the person understands the narrative nature of his/her identity but also that groups, societies, and cultures are positioned and construed through narratives (Clark \& Rossiter, 2008, 65). Pupils become aware of particular cultural 
narratives that define their understanding about themselves (e.g. gender roles) and society (e.g. what is valued). These narratives are situated in a certain time and place and can vary between different countries and societies. Learning through stories comes close to the ideas of critical pedagogy since it increases pupils' awareness of the values these cultural narratives carry. Also, Goodson and Gill (2011) understand that narrative learning is an ongoing construction of one's personal life history that refers to stories people tell about themselves in relation to cultural narratives present in the society. These stories are always constructed and reconstructed in a certain context and in relation to a certain audience. In the educational context, the more pupils are aware of narrative structures they are surrounded by, the better they can also reflect what kind of story they are telling about themselves.

In worldview education, one of the main goals is to support the pupil's identity development (Miedema, 2014; NCCBE, 2014, 264-265). Given that narratives can be regarded as the primary scheme by which human existence is rendered meaningful' (Polkinghorne, 1988, 11), they provide us with the necessary tools to answer the question of who we are or what we want to become. In other words, narrative can be regarded as a tool for identity work (McAdams \& McLean, 2013). If you sincerely want to tell someone who you really are, the answer is usually associated with a life story, which reveals where you come from and what meaningful things have happened to you. In other words, you are 'narratively constituted and narratively positioned' (Clark \& Rossiter, 2008, 65). One of the aims especially in worldview education is to make pupils aware of these structures and help them to critically reflect their views. These kinds of stories are very personal and private and, in order to enable and promote sharing of significant life experiences, a trustful atmosphere is needed. According to Jackson (2014), we need to have a safe space where pupils are able to express themselves without fear of being labelled in some way or considered ridiculous. He pinpoints a teacher's role of providing a socially safe learning environment where different opinions, values, and ways of life can be discussed in a respectful way. As a matter of fact, he considers this as a prerequisite if we want pupils to really reflect their own worldview in a classroom context.

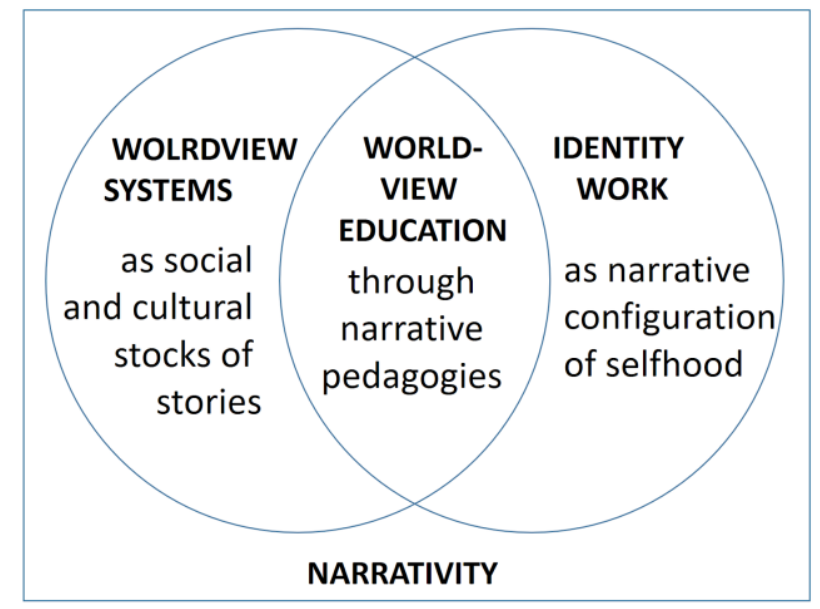

Figure 1: Worldview education as narrative identity work within the cultural stock of stories 
One's life story is never configured in a vacuum, but is situated in a given historical and social context, so every human life story is enmeshed within 'a community of life stories' (Bruner, 1987, 699), or a 'cultural stock of stories' (Hänninen, 2004), which refers to the 'totality of narrative representations that the person hears or reads in the course of his or her life, ranging from pieces of gossip and TV advertisements to novels and sacred texts, and from fairytales to real-life stories' (Hänninen, 2004, 73). When you want to tell someone who you are, your personal life story uses the cultural stock of stories as a resource from where you take models, forms, and patterns for your own narrative, most often unconsciously. (See figure 1). These forms and patterns not only apply to your told or written narrative, but also to your inner and lived narrative, so construing a narrative identity is an ongoing circulation between personal narratives and socially and culturally prefigured narratives.

Teachers work as interpreters of the cultural stock of narratives, including religious stories (Copley, 2007). It is worth noting whether a teacher transmits narratives without the opportunity to critique and reflect, or whether the social and cultural stocks of narratives are being used as a toolbox for diverse and alternative narrative identities, including a possibility for 'counter narratives' (Bamberg \& Andrews, 2004). Teachers are also in a key position on a larger scale, since they are teaching new members of the society and bringing their own values and attitudes to the teaching situation. Pedagogic practices are also a matter of power, teachers must acknowledge that power is an essential part of teaching and their response is to be conscious about it and help pupils to understand power structures. Some of these structures can maintain inequalities and stereotypes and teachers are obliged to be reflective about their practices. This also applies to learning contents, since some traditional sacred narratives are accused of promoting patriarchalism and violence (Pollefeyt \& Bieringer, 2005). Because of these power relations, teachers comprise an interesting area of study in the context of worldview education, where values and attitudes are strongly present.

\section{Data and methods}

The data of this study was gathered in Finland in the metropolitan area of Helsinki during spring 2016, and it is a part of wider research about teachers' pedagogical thinking and narrative pedagogy used in classrooms (see e.g. Keränen-Pantsu \& Rissanen, 2018). Six primary school teachers (5 female, 1 male teacher, referred to in the text as teachers 1-6), who teach children from 7-12 years old were interviewed individually using semi-structured interviews. All the teachers had been working for more than seven years and can be considered as experienced expert teachers. Because of that, they were assumed to be more aware of their teaching aims and teaching strategies than novice teachers and they constitute a good focus group for this research (see Kansanen, Tirri, Meri, Krorfors, \& Husu, 2000). All of them were teaching worldview education (1 teacher taught Lutheran RE, 1 Lutheran RE and Orthodox RE, 2 Lutheran RE and secular ethics, 2 Islamic RE), but it is worth noting that even though their classes were organized denominationally, (e.g. Muslim pupils study Islamic RE, 
Lutheran pupils Lutheran RE, etc.) the group of pupils in the classrooms were diverse, which also affects the teacher's role.

All interviews were conducted by the first author and the language used was Finnish. Citations in this article were translated into English by the first author. The theme of the interviews was teachers' pedagogical thinking and narrative pedagogy. The interviews could be described as in-depth, since the teachers reflected on their whole teaching career and the development of their pedagogy. The duration of the interviews varied from 59 minutes to $1 \mathrm{~h} 11$ minutes. Their aim was not to seek out representativeness, but rather to provide an opportunity to learn from the teachers on their own terms.

The analysis method was qualitative content analysis (see Elo \& Kyngäs, 2008). Analysis were carried out in an inductive manner which, according to Hatch (2002), means that 'analysis is a search for patterns of meaning in data so that general statements about phenomena under investigation can be made' (Hatch, 2002, 161). First, all the interviews were fully transcribed and carefully read through many times, then all the aims that teachers described for using narratives in the classroom were listed. An aim served as the unit of analysis and could consist of one to several sentences. Looking for bigger themes that combine the aims that teachers described, we end up identifying four main themes. An example of the process can be seen in Table 1 where the main theme comprises the main categories, subcategories and examples of the data. The first author made most of the coding, and cross-validation with the second author took place in some critical sections if there were some challenges in coding. According to Hatch (2002), this kind of analysis is well suited to interview data, where findings are the presentation of participant perspectives as captured in interview or focus group data (Hatch, 2002, 229-230).

Table 1: Sample of data analysis

\begin{tabular}{|l|l|l|l|}
\hline $\begin{array}{c}\text { Pedagogical } \\
\text { purpose }\end{array}$ & $\begin{array}{l}\text { Main } \\
\text { category }\end{array}$ & Sub-category & \multicolumn{1}{c|}{ Example of the data } \\
\hline $\begin{array}{l}\text { (1) to offer } \\
\text { knowledge } \\
\text { about } \\
\text { religions and } \\
\text { worldviews } \\
\text { to pupils }\end{array}$ & $\begin{array}{l}\text { aims } \\
\text { related } \\
\text { to } \\
\text { religious } \\
\text { aspects } \\
\text { of one's } \\
\text { culture }\end{array}$ & $\begin{array}{l}\text { to understand } \\
\text { the connection } \\
\text { between } \\
\text { religious } \\
\text { narratives and } \\
\text { religious } \\
\text { festivals }\end{array}$ & $\begin{array}{l}\text { '...that every pupil, when leaving the lower } \\
\text { classes of primary school would understand } \\
\text { the connection between the holidays of the } \\
\text { year and the life of Jesus.' (Teacher 1) } \\
\text { '...many things in our society and an } \\
\text { annual calendar and everything is based on } \\
\text { the Christian worldview or the Christian } \\
\text { doctrine. Festive calendar still is meaningful } \\
\text { and it is also general knowledge...' (Teacher } \\
\text { 3) }\end{array}$ \\
& & $\begin{array}{l}\text { 'well it is so that the biblical stories, the } \\
\text { to understand } \\
\text { the connection } \\
\text { between } \\
\text { different } \\
\text { forms of art } \\
\text { and religious part of the general common knowledge } \\
\text { as well, and they should be taught in } \\
\text { narratives }\end{array}$ & $\begin{array}{l}\text { school, of course, and they are of course } \\
\text { related to art, paintings...we can study } \\
\text { different paintings and stories behind } \\
\text { them.' (Teacher 4) }\end{array}$ \\
\hline & & &
\end{tabular}




\section{Results}

Table 2: Teachers' pedagogical purposes for using narratives in worldview education

\begin{tabular}{|c|c|}
\hline Pedagogical purposes & Main categories \\
\hline $\begin{array}{l}\text { (1) to offer knowledge about religions } \\
\text { and worldviews } \\
\text { to pupils }\end{array}$ & $\begin{array}{l}\text { Aims related to } \\
\text { content and historical context of } \\
\text { sacred narratives } \\
\text { religious dogma conveyed by } \\
\text { stories } \\
\text { practices of religion related to } \\
\text { stories } \\
\text { religious aspects of one's culture }\end{array}$ \\
\hline $\begin{array}{l}\text { (2) to reflect existential and } \\
\text { transcendental issues, }\end{array}$ & $\begin{array}{cl}\text { Aims related to } \\
. & \text { existence and nature of God } \\
. & \text { questions about life and death } \\
. & \text { human's place in the world } \\
. & \text { pupil's life questions }\end{array}$ \\
\hline (3) to develop ethical abilities & $\begin{array}{l}\text { Aims related to } \\
\text { everyday life situations (e.g. } \\
\text { stealing, friendships) } \\
\text { ethical thinking promoted by sacred } \\
\text { stories }\end{array}$ \\
\hline (4) to promote a sense of community & $\begin{array}{l}\text { Aims related to } \\
\cdot \quad \text { atmosphere and belonging }\end{array}$ \\
\hline
\end{tabular}

The teachers' pedagogical purposes for using narratives in worldview education was thematized into four main purposes (see Table 2). In the first category, narratives were a source to offer knowledge about religions and worldviews. The teachers said that it is part of common religious knowledge to know the basic religious narratives, since they are the basis of the whole belief system of particular religions. They attached great importance to pupils' understanding of how these traditional stories have affected the development and selfunderstanding of the religious community. There was also a need to enlighten the historical context from which the narratives have originated. For example, the message of the story of 'the Good Samaritan' will not be clear if you do not understand the societal status of Samaritan people and the purity regulations in the Jewish community. This was also applied to historical characters, like Martin Luther. In order to understand the role and significance to the development of the religious community, in this case Lutheranism, pupils must understand the circumstances and societal situation where the actions of Luther took place.

Religious doctrine, the core dogmatic content of, for example, Christianity was considered difficult to teach, since it often includes paradoxes, which could be 
difficult to understand, even for adults, not to mentions children with limitations in abstract thinking. Stories can serve as a way to approach such abstract content at the pupils' own level.

"The Easter story and Christmas story, I use to teach the doctrine of Christianity (...) I am able to teach (doctrines) through these stories, it is so symbolic and abstract, so it feels that the narrative is the only way to approach the doctrinal things in understandable way for children." (Teacher 1).

The teachers also considered it important for pupils to understand the religious festivals and their connections to sacred scriptures, and therefore the religious origins of the celebrations and the stories behind them. According to them, this kind of knowledge can be seen as general knowledge for understanding society. This category also included interaction between culture and religion. The teachers were worried about decreasing knowledge of religious literature, and the resultant deteriorating ability to understand the religious aspects of prevailing culture. The examples they used included the influence of the sacred stories, especially the Bible, which have been manifested in several form of art like paintings, sculptures, music, theatre, products of popular culture and religious symbolism in a broad sense. The teachers also said that modern forms of art like movies can also help children to understand religious narratives. They felt that lack of this kind of cultural knowledge is narrowing pupils' cultural competence.

"We are often talking about movies with children, because almost everything Jesus did, they've seen in Star Wars movie or somewhere. Like Jesus in the holy mountain, you have seen it in many movies when there is some guy, and he turns into a radiating light and he disappears from sight. So that is what Jesus did, so it went, and the pupils just said 'yeah'." (Teacher 5).

Narratives serve as a tool to reflect existential and transcendental issues in the second category. The teachers felt that using stories gave pupils the freedom to make their own interpretations and gave more space to discuss perennial questions, which have interested mankind for ages. Stories that include transcended themes like the nature of God seemed to interest pupils and act as a good starting point to share their own ideas. The Easter story helped pupils to think about what kind of God would sacrifice his own son, whether Judah and the priests were just evil when they convicted Jesus, or whether it was part of God's big plan to save mankind.

In the data, questions about life and death emerge from many perspectives. The teachers felt that if children were from a very religious home, it was more obvious to them what happens after death and no one in the class questioned it. This was mainly the case in Islamic RE at primary school level, where teachers of Islamic RE said that more open discussion could be found with upper secondary pupils who also consider other options. 
"It feels that for Muslim children it (the question of afterlife) is somehow so self-evident. It comes so strongly from home so that no big questions arise, they easily start to talk about the judgment day, life after death, and what happens to people. That's like a theory that has been heard many times." (Teacher 3).

Pupils' own life questions were considered important and, according to the teachers, using narratives could promote pupils' own reflections about their worldviews. When they were aware of different worldviews and belief systems, they were able to evaluate and create their own relationship to those systems and use them as building material for their own worldview. Lack of knowledge and the secularization of families was seen as problematic, since there was no space to have these discussions anymore.

Stories also carry on universal themes that have always been close to human lives. Humans have sought answers to eternal questions and also comfort when they have faced difficult life situations. This was described beautifully by one of the teachers who wants to bring hope to her pupils:

"Stories pass on the wisdom of life (...) Wisdom of life could be something like when things don't go as you wish or if you take a wrong path and still get to your destination, and how can something be blessing after all and what is important in life, family and other things." (Teacher 2).

Narratives were utilized to develop pupils' ethical abilities. There were two different approaches to dealing with ethical issues that occurred in this data: on the one hand, ethical stories that arise from the everyday situations of the pupils and, on the other, sacred, traditional narratives that carry an ethical aspect. According to the teachers, stories give the possibility to identify with different characters, and challenge pupils to think how they would act in certain situations. It also helps them to understand that ethical dilemmas are rarely simple and also have consequences for others.

“Stories support pupils' own thinking, pupils' own engagement and pupils' skill of empathy, for example the ability to walk in other people's shoes, and they also help them to understand the choices that characters make. They also show pupils situations, where it is difficult to act morally correctly, and help them to understand the complexity of the situations and choices people have to make and how choices affect others." (Teacher 2).

One reason for using narratives in ethical themes was to give pupils the chance to view their everyday choices from a distance and without the necessity to share their own experiences if the themes were too difficult or came too close to them. It also gave pupils the freedom to interpret the stories in their own ways, and teachers felt that the discussion was more open, not so prescriptive. When using sacred narratives, teachers felt it important to link stories to pupils' own lives, so that the universal message could also touch them. 


\begin{abstract}
"Most of the time I use narratives in ethical topics, because the story also works in difficult themes in a special way, you can look at it from the distance. Then teaching ethics is not only about telling pupils how they should behave." (Teacher 1).

"In the context of worldview education the question of right and wrong like lying and stealing, so how do you act or behave right between friends or at home. So, the easiest way to teach these themes is with stories." (Teacher 3 ).
\end{abstract}

The teachers described how using narratives and especially traditional storytelling sessions promoted a sense of community in the classroom. When pupils come together and calm down to listen, there is something that seems to pacify them and touch their inner world. Some teachers even used the word holy experience' when, after the story, everyone sits in silence and the atmosphere is tranquil and respectful. These kinds of working methods also reveal whether there is something going on in the class like bullying or exclusion. Pupils don't want to share their own ideas provoked by the narrative, not to mention their real-life experiences, if they do not feel safe enough. Thus, using narratives in the classroom can work as an indicator for atmosphere.

"Pupils have to feel themselves safe in the classroom so that they dare to participate for real and also that there's no right or wrong answers, and that all that is said is valuable. And if there is something in the atmosphere, something affiliated to bullying, it's paralyzing everything. You can ask for their homework and they answer, but if you have to share something genuinely personal, it's not working." (Teacher 4).

Teachers also attach great importance to an open atmosphere, which also allows interpretations other than those highlighted by the religious community. This also requires a confidential learning environment so that pupils dare to approach narratives with a critical sense.

"It requires that the community where the interpretations is done has a permissive atmosphere. So, if the community is not supporting you to express yourself... So... This is complicated, it's not only about narratives, it's linked to the classroom community and that community, where...[the origins of the story are]." (Teacher 6).

\title{
Discussion and conclusions
}

The aim of this study was to investigate for what purposes teachers use narratives in worldview education. We found four main aims for using narratives (1) to offer knowledge about religions and worldviews; (2) to reflect on existential and transcendental issues; (3) to develop ethical abilities and (4) to promote a sense of community. 
According to our data, all the teachers have used narratives in multiple ways, and all the categories found in the data were present in every interview. More variety would have been expected; although all the teachers were teaching at the primary level, they represent both subjects of the Finnish curriculum, namely secular ethics and religious education. This finding was somewhat surprising given that, according to the curriculum (NCCBE, 2014), the role of narratives in teaching is more central in religious education than in secular ethics; in other words, the narrative cognition (Bruner, 1987) is more explicitly present in religious education than in secular ethics.

Teachers understood that narratives open up possibilities for offering knowledge (Category 1) and for existential and transcendental reflection (Category 2). As pointed out by Shelduck and Valk (2012), religious and nonreligious worldviews provide perspectives on ontological, existential and epistemological questions on different levels, and these elements, especially existential and epistemological issues, were present in our results (Categories 1 and 2). Narratives also seem to develop ethical ability (Category 3). Dealing with narratives helps pupils understand that many values present in our society, like respecting others, helping your neighbor, nurturing nature, etc., have their roots in religions and humanism, for example. Reflecting on questions about values, existence and ethical behavior also helps pupils to realize that they are surrounded by metanarratives or 'cultural stocks of stories' (Hänninen, 2004), and this affects how they see the world and themselves. This kind of critical reflection is also one of the main goals of worldview education at curriculum level (NCCBE, 2014). In other words, the teachers wished to promote pupils' narrative identity work, although they did not express this explicitly. This was done by stressing the two forms of learning through stories stated by Clark and Rossiter (2008): learning by hearing stories and learning by telling stories. The third form of learning suggested by Clark and Rossiter, learning by recognizing stories, was not so explicitly present and was rather deduced. Moreover, although teachers encourage pupils to reflect on their own life questions, the dimension of contextualizing the autobiographical narratives of pupils (Goodson \& Gill, 2011) seems not to be acknowledged by teachers and needs to be more emphasized.

One of the most significant findings of this study was the use of narratives for promoting a sense of community. In current RE literature, safe space (Jackson, 2014) is referred to as a tolerant atmosphere where different worldviews are recognized and can be present without fear of being stereotyped, discriminated against or ridiculed. However, finding concrete ways of accomplishing this kind of space is not an easy task, and many teachers feel unconcerned when they are not aware what is happening in social relationships in the classroom. The teachers felt that using narrative pedagogy in the classroom promoted pupils' sense of community in a special way. The teachers described how settling down with a story somehow connects pupils and encourages them to participate and share the thoughts created by narrative. On the other hand, stories also worked as indicators of atmosphere and can reveal if the space is trustful enough to share your ideas and explain your own worldview. Narrative pedagogy seemed to offer a useful tool to teachers to advance the conditions for creating safe space 
in a classroom environment and promote dialogue enabling worldview reflection.

How to promote a sense of community through narratives in diverse learning communities is an intriguing task as social cohesion and inclusion are not easy to achieve when school brings together pupils from very different backgrounds. It is interesting that, according to the present study, shared narratives can be the 'thing' that promotes a sense of community. There is, however, a risk that paying attention to sacred narratives may exclude pupils (see e.g. Poulter, Riitaoja, \& Kuusisto, 2016). Teachers in this study highlighted that stories that convey universal humanistic themes, such as how to cope with difficulties in life, touch pupils regardless of their background or worldview.

Categories found in the data represent aims and goals described by teachers of worldview education. However, we want to emphasize that these categories overlap in many ways. For example, when pupils reflect the essence of God in the Easter story, they also ponder ethical dilemmas present in the story. Thus, we highlight that the four categories found in this study must be regarded as an ideal typography and, in reality, they intersect. It appears that in Finland, according to this study, teachers' focus is on using the stock of religious narratives as a resource for reflective, critical and pluralist education so as to promote the personal identity work of the pupils. However, given the restriction of the small data size and an emphasis on experienced teachers in our sample, further research is needed. According to our study, narratives also have much to offer for pluralistic education, opening up diverse ways of viewing the world. Because of its central role, the narrative approach also shows promising potential for further research about worldview education.

\section{References}

Bamberg, M., \& Andrews, M. (Eds.). (2004). Considering counter-narratives: Narrating, resisting, making sense (Vol. 4). John Benjamins Publishing.

Basic Education Act 628/1998, $13 \S(6.6 .2003 / 454)$ Retrieved from https://www.finlex.fi/fi/laki/kaannokset/1998/en19980628.pdf

Biesta, G. J. J., \& Miedema, S. (2002). Instruction or pedagogy? The need for a transformative conception of education. Teaching and Teacher Education 18. 173181.

Bruner, J. (1987). Life as narrative. Social research, 1987, 11-32.

Clark, M. C., \& Rossiter, M. (2008). Narrative learning in adulthood. New directions for adult and continuing education, (119), 61-70.

Copley, T. (2007). The Power of the Storyteller in Religious Education. Religious Education 102 (3): 288-297. doi:10.1080/00344080701496264

Egan, K., \& McEwan, H. (Eds.). (1995). Narrative in teaching, learning, and research. Teachers College Press.

Elo, S., \& H. Kyngäs. 2008. The Qualitative Content Analysis Process. Journal of Advanced Nursing, 62(1): 107-115. doi:10.1111/j.1365-2648.2007.04569.x.

Erricker, C., \& Erricker, J. (2000). Reconstructing religious, spiritual, and moral education. Psychology Press. 
Geertz, A. W., \& Jensen, J. S. (2014). Religious narrative, cognition and culture: image and word in the mind of narrative. Routledge.

Goodson, I., \& Gill, S. (2011). Narrative pedagogy: Life history and learning. New York: Peter Lang.

Grimmit, M. (1987). Religious Education and Human Development: The Relationship between Studying Religions and Personal, Social and Moral Education. Great Wakering: McCrimmons.

Halstead, J. M., \& Taylor, M. J. eds. (1996). Values in Education and Education in Values. London: The Falmer Press.

Hatch, J. A. (2002). Doing Qualitative Research in Education Settings. State University of New York Press.

Heikkinen, H. (2002). Whatever is Narrative Research? In Huttunen, R., Heikkinen, H., \& Syrjälä, L. (Eds.) Narrative research. Voices of Teachers and Philosophers (pp. 1328). Jyväskylä: SoPhi.

Heimbrock, H-G. (2001). Introduction. In Heimbrock, H-G., Sheilke, C., \& P. Scheiner, P. (eds.), Towards Religious Competence. Diversity as a Challenge for Education in Europe (pp. 3-11). Schriften aus dem Comenius-Institut. Múnster: Lit.

Hyvärinen, M. (2010). Revisiting the narrative turns. Life Writing, 7(1), 69-82. doi:10.1080/14484520903342957

Hänninen, V. (2004). A model of narrative circulation. Narrative inquiry, 14(1), 69-85. doi:https://doi.org/10.1075/ni.14.1.04han

Jackson, R. (2014). Signposts-policy and practice for teaching about religions and non-religious world views in intercultural education. Council of Europe.

Kallioniemi, A., \& Ubani, M. (2016). Religious Education in Finnish School System. In Niemi, H., Toom, A., \& Kallioniemi, A. (eds.) Miracle of Education (pp. 177-188). Rotterdam: Sense Publishers.

Kansanen, P., Tirri, K., Meri, M., Krokfors, L., \& Husu, J. (2000). Teachers' Pedagogical Thinking: Theoretical Landscapes, Practical Challenges. New York: Peter Lang.

Keränen-Pantsu, R., \& Rissanen. I. (2018). What kind of tensions are involved in the pedagogical use of religious narratives? Perspectives from Finnish Evangelic Lutheran and Islamic religious education. Journal of Beliefs \& Values, 157-168. doi:10.1080/13617672.2018.1450804

van der Kooij, J., de Ruyter, D. \& Miedema, S. (2015). Can We Teach Morality Without Influencing the Worldview of Students? Journal of Religious Education 63(2), 7993. doi:10.1007/s40839-016-0022-4

National Core Curriculum for Basic Education. [Perusopetuksen opetussuunnitelmien perusteet] (2014). Finnish National Agency for Education. Accessed September 25, $2018 . \quad$ Retrieved from http://oph.fi/download/163777_perusopetuksen_opetussuunnitelman_peruste et_2014.pdf (in Finnish).

McAdams, D. P., \& McLean, K. C. (2013). Narrative identity. Current directions in psychological science, 22(3), 233-238. doi: 10.1177/0963721413475622

Miedema, S. (2014). Worldview Education and Beyond: The Strength of a Transformative Pedagogical Paradigm. Journal for the Study of Religion 27(1), 82103.

Moore, D. L. (2016). Diminishing religious literacy: Methodological assumptions and analytical frameworks for promoting the public understanding of religion. In A. Dinham, \& M. Francis (Eds.), Religious literacy in policy and practice (pp. 27-38). Bristol: Policy Press.

Polkinghorne, D. E. (1988). Narrative knowing and the human sciences. Suny Press. 
Pollefeyt, D., \& Bieringer, R. (2005). The Role of Bible in Religious Education Reconsidered. Risks and Challenges in Teaching the Bible. International Journal of Practical Theology 9: 117-139. doi:https:// doi.org/10.1515/IJPT.2005.007

Poulter, S., Riitaoja, A-L., \& Kuusisto, A. (2016). Thinking multicultural education 'otherwise' - from a secularist construction towards a plurality of epistemologies and worldviews. Globalization, Societies, Education 14(1) 68-86. doi:10.1080/14767724.2014.989964

Smart, N. (1989). The world religions. Cambridge: Cambridge University Press.

Smart, N. (1996). Dimensions of the sacred: An anatomy of the world's beliefs. Berkeley/Los Angeles: University of California Press.

Smart, N. (2008). World philosophies. London and New York: Routledge Taylor \& Francis.

Selcuk, M., \& Valk, J. (2012). Knowing Self and Others: A Worldview Model for Religious Education in Turkey. Religious Education 107(5), 443-454. doi:10.1080/00344087.2012.722473

Åhs, V., Poulter, S., \& Kallioniemi, A. (2017). Preparing for the world of diverse worldviews: parental and school stakeholder views on integrative worldview education in a Finnish context. British Journal of Religious Education 40(1), 78-89. doi: 10.1080/01416200.2017.1292211 